\title{
Characteristics of micromorphology and element distribution of iron-manganese cutans in typical soils of subtropical China
}

\author{
Li Huang a , Jun Hong a , Wenfeng Tan ${ }^{a}$, Hongqing Hu ${ }^{a}$, Fan Liu ${ }^{\text {a,* }}$, Mingkuang Wang ${ }^{b}$ \\ ${ }^{a}$ Key Laboratory of Subtropical Agriculture Resources and Environment, Ministry of Agriculture, Huazhong Agricultural University, 430070, Wuhan, Hubei Province, China \\ ${ }^{\mathrm{b}}$ Department of Agricultural Chemistry, National Taiwan University, Taipei, 106, Taiwan
}

\section{A R T I C L E I N F O}

Article history:

Received 1 December 2007

Received in revised form 11 April 2008

Accepted 6 May 2008

Available online 18 June 2008

\section{Keywords:}

Iron-manganese cutan

Micromorphology

Element distribution

$\mathrm{MnO}_{2}$

$\mathrm{Fe}_{2} \mathrm{O}_{3}$

\begin{abstract}
A B S T R A C T
The goal of this study was to investigate the characteristics of iron-manganese cutans and to observe information of their pedogenic processes and certain environmental condition changes in the pedogenic process of subtropical Chinese soils. The characteristics of micromorphology of iron-manganese cutans and element distribution with linear microprofiles (i.e., the vertical microprofile from cutan to matrix soil) in Fragiudalfs (FRA), Ferrudalfs (FER) and Hapludult (HAP). Cutans and matrix soils were studied by chemical analyses, optical microscopy (OM) and energy dispersive spectroscopy (EDS). The micromorphological structure of iron-manganese cutan was a thin black film with alternating color of red and brown, and about $1 \mathrm{~mm}$ thick of soil particles. The structures of cutan materials were denser, and the boundaries between cutans and matrix soils were clear. EDS analyses of cutans and the plasma phase of the matrix soils, showed that the contents of $\mathrm{MnO}_{2}, \mathrm{Fe}_{2} \mathrm{O}_{3}$ and $\mathrm{CaO}$ in cutans were higher than those in matrix soils, while the content of $\mathrm{SiO}_{2}$ showed the opposite trend. From the outer to inner, cutans in Fragiudalfs and Ferrudalfs can be easily fractionated into manganese-rich, iron-manganese-rich and iron-rich regions. But there were only iron-manganese-rich and iron-rich regions in cutans in Hapludult, there was no clear manganese-rich region of belt structure in it. These differences were attributed to soil-forming factors. The formation of belt structure in iron-manganese cutans would probably undergo several great change in landscapes and soil environments. It indicated that the growth of cutans was in environments of alternating wetting and drying. They gradually grew in the oxidation-reduction process on the dry or wet condition of whole bulk soils.
\end{abstract}

Crown Copyright @ 2008 Published by Elsevier B.V. All rights reserved.

\section{Introduction}

Soil cutans form gradually in the long-term soil pedogenic processes. They are one of the common fabric features and information carrier of element movement and solid-solution-plant-air interaction in soils (Brewer, 1976; Jongmans et al., 1993, 1994, 1996; Liu et al., 2002b). The shape, structure and elemental composition characteristics of cutan were the products of soil-forming processes and environmental conditions (Buol and Hole, 1959; Chartres, 1987; Hartres, 1987; Feijtel et al., 1989; Sullivan and Koppi, 1991; Payton, 1993; Boulet et al., 1998; McCarthy et al., 1999; Tsatskin and Ronen, 1999). It can serve as an important basis for identifying the pedogenic processes and the environmental variations in different periods (Jongmans et al., 1996; Padmanabhan and Mermut, 1996; Hopkins and Franzen, 2003).

It was reported that the growth complexities of ferri-agillans formed in fossil soils indicated that these soils had undergone basic soil erosion and deposition process from moist to semiarid in ferruginous soil in Indian (Venugopal, 1998). Ferruginous clay cutans

\footnotetext{
* Corresponding author. College of Resources and Environment, Huazhong Agricultural University, 430070, Wuhan, Hubei Province, China. Tel.: +86 2787280271.

E-mail address: liufan@mail.hzau.edu.cn (F. Liu).
}

on the surface of Australian podzol particles revealed that the soil had been periodic flooded in the soil soil-forming process (Harris et al., 1987). It could be extrapolated that the forming process of cutans was intermittent through analyzing the relationship between the shapes and oriented types of different cutans (Rebertus and Buol, 1985; Robinson, 1993). The morphology of the clay coating indicated that the vesicles in a desert loam soil (Haplic Durargid) in Australia had considerable durability (Sullivan and Koppi, 1991). Size and frequency of microcrystalline calcite coatings increased from aridic to xeric moisture regime, but decreased again towards the areas with an ustic moisture regime in highly calcareous arid and semiarid soils of the Fars Province, Southern Iran (Khormali et al., 2006). Carbonate coatings in stony soils were stratified into distinct microlamina, which provided a record of local environmental changes. Their growth rates could be employed to evaluate the age of paleograssland of arid and semiarid regions in Germany (Pustovoytov, 2002). These studies had all verified that cutans were the micro-environment recorders for the activity, migration and illuviation of specific components in soils. It also served as information carriers for the soil-forming process, environmental changes and paleoclimatic transitions.

Iron and manganese oxides as well as hydroxide minerals are very active constituents in soils because they are sensitive to environmental 
changes and they move frequently along soil cracks or holes and deposit in peds (McKenzie, 1989; Dixon and Skinner, 1992). As the condition changes from that of reduction to oxidation, iron and manganese may become immobilized (Padmanabhan and Mermut, 1996; Tan et al., 2005). In soils, the reduction and oxidation of iron and manganese, as a result of seasonal changes in soil moisture, contributes to the formation of cutans, forming coatings and concretions (Hartres, 1987; Robinson, 1993; Zhang and Karathanasis, 1997; Liu et al., 2002a,b). Mn(II) possesses higher mobility in soil profile than iron, holding a high oxidation potential compared with Fe(II) (Lindsay, 1979). These differences contribute to the formation of alternate layers with variable distribution of iron and manganese oxides in cutans, reflecting the wetting and drying variations in soil microenvironments that enclose in the cutans.

Iron-manganese cutans are widely distributed in Alfisol and Ultisols in subtropical zone in China. The behavior of chemical elements in these cutans was affected by climatic changes, landforms and land use (Tan et al., 2005; Huang et al., 2007). The migration and deposition of massive iron-manganese oxides in these soils was changed under different micro-environmental situations. Thus, elemental distributions with linear microprofiles in different iron-manganese cutans should have different characteristics in subtropical soils, but related research was extremely limited. The aims of the present study were (i) to determine the microscopic characteristics of iron-manganese cutans through analyzing the shape, microstructure and chemical composition with their linear microprofiles, and (ii) to identify the pedogenic processes, which response for their characteristics, and (iii) to observe information of certain environmental changes in the pedogenic processes of these subtropical Chinese soils.

\section{Materials and methods}

\subsection{Soil sampling and descriptions}

Three representative soils with iron-manganese cutans in B horizons from different subtropical regions in central China, were collected for this study. They are Fragiudalfs, Ferrudalfs and Hapludult, according to Key to Soil Taxonomy (Soil Survey Staff, 2006), collected from Xinyang city $\left(32^{\circ} 22^{\prime} \mathrm{N}, 114^{\circ} 39^{\prime} \mathrm{E}\right)$ in Henan Province, Wuhan City $\left(30^{\circ} 42^{\prime} \mathrm{N}, 114^{\circ} 24^{\prime} \mathrm{E}\right)$ in Hubei Province and Taoyuan City $\left(28^{\circ} 52^{\prime} \mathrm{N}\right.$, $111^{\circ} 27^{\prime} \mathrm{E}$ ) in Hunan Province, respectively. Climatic data and description of the studied samples were listed in Table 1 . These soils were all from barren lands on the upper part of slopes. The landscapes of these areas are hills with good drainage condition. The B horizons in these soils usually exhibit a coarse polyhedral to columnar structure. The subangular blocky peds (matrix soils) that contain cutans were collected from the B horizon at the depth about $20-50 \mathrm{~cm}$. The cutans were usually black or brown in color and showed a waxy luster. Six to eight representative reddish-brown iron-manganese cutans (i.e., at least $30 \mathrm{~g}$ ) were collected from each kind of B horizon soil. The cutan samples only were black or brown materials collected with a sterile blade under a microscope from soil blocks lightly. Matrix soils (i.e., at least $25-30 \mathrm{~kg}$ ) were collected from adjacent ped interior blocks that scraped off cutans. Cutans were air-dried in original sample phases. The air-dried matrix soils and part of cutans were ground to pass 10-, 20-, 60- and 100-mesh sieves, respectively.

\subsection{Soils and cutans chemical and physical analyses}

Soil pH was measured by a Thermo Orion pH meter (Model 868) using a combined glass electrode (Model 9165BN) with a 1:2.5 ratio of soil to water. Cation-exchange capacity (CEC) of soils tested was determined according to the method described by Jackson (1979). The contents of organic matter in samples were determined following the $\mathrm{K}_{2} \mathrm{Cr}_{2} \mathrm{O}_{7}$ volumetric methods (Walkley and Black, 1934). The particle-size distribution was determined by the pipette method after hydrogen peroxide treatment (Gee and Bauder, 1986).

The samples were digested with aqua regia $\left(\mathrm{HNO}_{3}: \mathrm{HCl}=1: 3\right)$ $\left(125^{\circ} \mathrm{C}\right.$ ) to extract iron (Fe) and manganese (Mn) (Liu et al., 2002b). Exchangeable $\mathrm{K}, \mathrm{Na}, \mathrm{Ca}$, Mg were extracted with $1 \mathrm{~mol} \mathrm{~L}^{-1} \mathrm{NH}_{4} \mathrm{OAc}$. $\mathrm{K}$ and Na were measured with a flame photometer (FP-640). Ca, Mg, Fe and $\mathrm{Mn}$ were determined using an atomic spectrophotometer (Varian AA240FS). Extractable X-ray noncrystalline Fe (Feo) was dissolved in ammonium oxalate solution (i.e., $0.2 \mathrm{M}, \mathrm{pH} 3.0,4 \mathrm{~h}$ in dark) (McKeague and Day, 1966), and free Fe Fe-oxide (Fed) was dissolved in dithionite-carbonate-citrate (DCB, free Fe-oxide) (Mehra and Jackson, 1960).

Deferrated clay samples were saturated with $\mathrm{Mg}$ and $\mathrm{K}$ and mounted as slurries on petrographic slides for X-ray diffraction analysis (Jackson, 1979). The Mg-saturated clays were X-rayed at $25^{\circ} \mathrm{C}$ before and after glycerol salvation. The K-saturated clays were X-rayed at $25{ }^{\circ} \mathrm{C}$ before and after heating at $110,250,350,450$ and $550{ }^{\circ} \mathrm{C}$ for $2 \mathrm{~h}$ (Jackson, 1979). Part of the clay fractions without DCB treatments were was separated into magnetic and non-magnetic fractions (Schulze and Dixon, 1979). Soil clays were quantitatively separated using DCB treatments. Clays were treated by ultrasonic dispersion in pH $9.5 \mathrm{Na}_{2} \mathrm{CO}_{3}$ solutions and then passed through the magnetic field of a strong electromagnet. Flow rate for water was $0.05 \mathrm{~L} \mathrm{~min}^{-1}$. All clay suspensions were fractionated at $0.9 \mathrm{~T}$ to separate the non-ironbearing minerals. After high-gradient magnetic separation (HGMS)

Table 1

Climate data and description of the samples tested

\begin{tabular}{|c|c|c|c|c|c|c|}
\hline \multirow[t]{2}{*}{ Sample } & \multirow[t]{2}{*}{ Location } & \multirow[t]{2}{*}{ Parent material } & \multirow{2}{*}{$\frac{\text { Mean annual rainfall }}{\mathrm{mm}}$} & \multirow{2}{*}{$\frac{\text { Mean annual temperature }}{{ }^{\circ} \mathrm{C}}$} & \multirow[t]{2}{*}{$\begin{array}{l}\text { Soil moisture and } \\
\text { temperature regime }\end{array}$} & \multirow[t]{2}{*}{ Description } \\
\hline & & & & & & \\
\hline Cutan of FRA ${ }^{\mathrm{a}}$ & \multirow[t]{2}{*}{ Xinyang Henan } & \multirow[t]{2}{*}{ Quaternary $\left(\mathrm{Q}_{3}\right)$} & \multirow[t]{2}{*}{670} & \multirow[t]{2}{*}{$12.8-15.5$} & \multirow[t]{2}{*}{ Udic-mesic } & Reddish black moist color (10R 2/1) \\
\hline Matrixof FRA & & & & & & $\begin{array}{l}\text { Strong brown ( } 7.5 \text { YR } 5 / 6) \text {; light clay; } \\
\text { weak/moderate subangular blocky } \\
\text { structure; very firm; some cutans }\end{array}$ \\
\hline Cutan of FER ${ }^{b}$ & \multirow[t]{2}{*}{ Wuhan Hubei } & \multirow[t]{2}{*}{ Quaternary $\left(Q_{3}\right)$} & \multirow[t]{2}{*}{1269} & \multirow[t]{2}{*}{$15.8-17.5$} & \multirow[t]{2}{*}{ Udic-thermic } & Yellowish block moist color ( $5 Y$ 2/1) \\
\hline Matrix of FER & & & & & & $\begin{array}{l}\text { Yellowish red (5YR 5/8); clay; } \\
\text { weak/moderate subangular blocky } \\
\text { structure; very firm; many cutans }\end{array}$ \\
\hline Cutan of $\mathrm{HAP}^{\mathrm{C}}$ & \multirow[t]{2}{*}{ Taoyuan Hunan } & \multirow[t]{2}{*}{ Quaternary $\left(Q_{2}\right)$} & \multirow[t]{2}{*}{1437} & \multirow[t]{2}{*}{$16.0-16.5$} & \multirow[t]{2}{*}{ Udic-thermic } & Reddish black moist color (10R $2 / 1)$ \\
\hline Matrix of HAP & & & & & & $\begin{array}{l}\text { Reddish yellow ( } 7.5 Y R \text { 6/8); clay; } \\
\text { moderate subangular blocky structure; } \\
\text { very firm; many cutans }\end{array}$ \\
\hline
\end{tabular}

\footnotetext{
a FRA $=$ Fragiudalfs

b FER $=$ Ferrudalfs.

c $\mathrm{HAP}=$ Hapludult.
} 
Table 2

Selected soil chemical and physical properties

\begin{tabular}{|c|c|c|c|c|c|c|c|c|c|c|c|}
\hline \multirow[t]{3}{*}{ Sample type } & \multirow[t]{3}{*}{$\mathrm{pH}^{\mathrm{a}}$} & \multirow{3}{*}{$\begin{array}{l}\text { O.M. }^{\mathrm{b}} \\
\overline{\mathrm{mg} \mathrm{g}^{-1}}\end{array}$} & \multicolumn{4}{|c|}{ Exchangeable cation } & \multirow[t]{2}{*}{ B.S. $^{c}$} & \multirow[t]{2}{*}{ CEC } & \multirow[t]{2}{*}{ Sand } & \multirow[t]{2}{*}{ Clay } & \multirow[t]{3}{*}{ Texture } \\
\hline & & & K & $\mathrm{Na}$ & $\mathrm{Ca}$ & $\mathrm{Mg}$ & & & & & \\
\hline & & & \multicolumn{4}{|c|}{$\mathrm{cmol} \mathrm{kg}^{-1}$} & $\%$ & $\mathrm{cmol} \mathrm{kg}^{-1}$ & $\mathrm{~g} \mathrm{~kg}^{-1}$ & $\mathrm{~g} \mathrm{~kg}^{-1}$ & \\
\hline Cutan of FRA & 6.60 & 10.56 & 0.66 & 1.08 & 6.05 & 4.50 & 42.07 & 29.21 & 186.1 & 535.6 & $\mathrm{C}^{\mathrm{d}}$ \\
\hline Matrix of FRA & 6.44 & 8.14 & 0.23 & 0.78 & 4.50 & 3.50 & 46.81 & 19.25 & 363.8 & 395.8 & $\mathrm{CL}^{\mathrm{e}}$ \\
\hline Cutan of FER & 5.93 & 3.35 & 0.38 & 1.12 & 4.05 & 3.66 & 45.06 & 20.44 & 214.6 & 514.8 & C \\
\hline Matrix of FER & 5.81 & 3.01 & 0.20 & 0.51 & 3.90 & 3.33 & 53.65 & 14.80 & 208.8 & 457.7 & $\mathrm{C}$ \\
\hline Cutan of HAP & 4.41 & 3.61 & 0.32 & 0.15 & 2.70 & 2.25 & 35.85 & 15.12 & 250.3 & 547.8 & C \\
\hline Matrix of HAP & 4.25 & 3.24 & 0.20 & 0.09 & 1.55 & 1.66 & 34.15 & 10.25 & 141.8 & 462.5 & C \\
\hline
\end{tabular}

a Soil: $\mathrm{H}_{2} \mathrm{O}=1: 2.5$

b O.M. = organic matter.

c B.S.= base saturation.

d $\mathrm{C}=$ clay.

e $\mathrm{CL}=$ clay loam.

treatments, clay suspensions were flocculated with $\mathrm{NaCl}$, and excess salts were removed by centrifugation, washed by distilled water and freeze-dried. Clay minerals analysis was carried out with XRD techniques (Fe K $\alpha$ radiation generated at $40 \mathrm{kV}$ and $20 \mathrm{~mA}$ ) using a D/Max-3B diffractometer (JDX-10P3A) on clay fractions of cutan and matrix soil before and after HGMS or DCB treatments.

\subsection{Optical microscopy and electron microscopy of sample}

Cutans were impregnated with polyester resin (crystic) to solidify, then cut along the vertical direction of cutan surface into impregnated blocks and burnished into several thin sections (FitzPatrick, 1984). Thin section samples were investigated with a polarizing microscope (Opton Universal R Pol) using polarized light. The enlarged multiple was 10 or 40 times.

Selected representative thin section samples were coated with carbon in a vacuum evaporator, and then examined with energy dispersive spectrometer (EDS) (JCXA-733) operated in an automated quantitative elemental analysis mode that performed at $15 \mathrm{kV}$ and $20 \mathrm{~mA}$ and $2 \mu \mathrm{m}$ microtie diameter, using metals of Si, Ti, Al, Fe, Mn, K, $\mathrm{Na}, \mathrm{Ca}$ and $\mathrm{Mg}$ as standard. The measured element contents in cutan with linear microprofiles were converted into oxide contents, and the coefficients of variation for oxide contents were obtained with Excel 2003.

\section{Results}

\subsection{Properties and morphology of iron-manganese cutans}

The soil texture of samples ranged from clay to clay loam. From Fragiudalfs, Ferrudalfs to Hapludult, pH decreased obviously while the contents of $\mathrm{Fe}_{2} \mathrm{O}_{3}$, clay and kaolinite increased, with gradually decreasing base saturation and vermiculite contents (Tables 2 and 3 ). The $\mathrm{pH}$, organic matter, exchangeable cations, $\mathrm{CEC}$, clay, $\mathrm{Fe}_{2} \mathrm{O}_{3}, \mathrm{MnO}_{2}$, Feo contents of the cutans of three soils were all higher than those of matrix soils in B horizon (Tables 2 and 3). The contents of Fed in cutans of Fragiudalfs and Hapludult were lower than those in matrix soils in B horizons. The Feo to Fed molar ratio of cutans was higher than that of matrix soils. This is mainly due to the organic matter contents and moistures of cutans were richer than those in matrix soils, and the source and forming time of Fe-oxide in cutans were shorter than those in matrix soils. The difference in $\mathrm{MnO}_{2}$ content between cutans and matrix soils was marked. The contents of $\mathrm{MnO}_{2}$ in cutans were 1.27-19.31 times greater than those in matrix soils. Vermiculite, illite and kaolinite are major clay compositions in both cutans and matrix soils. It had been reported that hydroxy-interlayered vermiculite (HIV) existed in matrix soils of Fragiudalfs and Ferrudalfs (Huang et al., 2007). The type of Fe-oxide was goethite in cutans and matrix soils. The Mn-oxides in cutans of three soils contained low contents of birnessite and lithiophorite, but they could not be detected in corresponding matrix soils.

Fig. 1 showed optical micrographs of iron-manganese cutans under crossed polarized light of three soils. The black films alternating with red and brown in the middle-upper side of the micrographs was cutans. Cutan in Fragiudalfs of Xinyang City (Fig. 1(a)) formed a thin film on the surface of soil block, and was obviously different from the matrix soil. It consisted of black $\mathrm{MnO}_{2}$ and red $\mathrm{Fe}_{2} \mathrm{O}_{3}$ from the outer to inner cutan layer, and the transition was obvious on the edge of cutan. After being magnified 40 times (Fig. 1(b)), the cover of $\mathrm{MnO}_{2}$ on the surface of cutans could be observed and it alternated with red $\mathrm{Fe}_{2} \mathrm{O}_{3}$, indicating that there was massive deposition of $\mathrm{MnO}_{2}$ and $\mathrm{Fe}_{2} \mathrm{O}_{3}$ on the cutans of Fragiudalfs.

Table 3

Soil sesquioxide contents and clay mineralogical compositions

\begin{tabular}{|c|c|c|c|c|c|c|c|}
\hline \multirow[t]{2}{*}{ Sample type } & \multirow{2}{*}{$\frac{\mathrm{Fe}_{2} \mathrm{O}_{3}}{\mathrm{mg} \mathrm{g}^{-1}}$} & \multirow{2}{*}{$\frac{\mathrm{MnO}_{2}}{\mathrm{mg} \mathrm{g}^{-1}}$} & \multirow{2}{*}{$\frac{\mathrm{Feo}^{\mathrm{a}}}{\mathrm{mg} \mathrm{g}^{-1}}$} & \multirow{2}{*}{$\frac{\mathrm{Fed}^{\mathrm{b}}}{\mathrm{mg} \mathrm{g}^{-1}}$} & \multirow[t]{2}{*}{ Feo/Fed } & \multirow[t]{2}{*}{ Clay mineralogical composition $^{c}$} & \multirow[t]{2}{*}{ Fe and Mn oxides } \\
\hline & & & & & & & \\
\hline Cutan of FRA & 57.07 & 9.97 & 2.95 & 21.36 & 0.14 & $\mathrm{~V}(++), \mathrm{I}(++++), \mathrm{K}(+)$ & G, B, L \\
\hline Matrix of FRA & 45.93 & 0.86 & 1.71 & 22.72 & 0.08 & $\mathrm{~V}(++), \mathrm{H}(+), \mathrm{I}(++++), \mathrm{K}(++)$ & G \\
\hline Cutan of FER & 62.37 & 10.04 & 5.35 & 36.07 & 0.15 & $\mathrm{~V}(++), \mathrm{I}(++++), \mathrm{K}(++)$ & $\mathrm{G}, \mathrm{B}, \mathrm{L}$ \\
\hline Matrix of FER & 45.56 & 0.52 & 1.41 & 31.22 & 0.05 & $\mathrm{~V}(+), \mathrm{H}(+), \mathrm{I}(++++), \mathrm{K}(++)$ & G \\
\hline Cutan of HAP & 60.76 & 5.83 & 6.94 & 40.28 & 0.17 & $\mathrm{~V}(+), \mathrm{H}(+), \mathrm{I}(++++), \mathrm{K}(++)$ & G, B, L \\
\hline Matrix of HAP & 56.53 & 0.66 & 1.45 & 46.74 & 0.03 & $\mathrm{~V}(+), \mathrm{H}(+), \mathrm{I}(++++), \mathrm{K}(+++)$ & G \\
\hline
\end{tabular}

a Oxalate-extracted iron.

b Dithionite-citrate-bicarbonate-extracted iron.

c $\mathrm{V}=$ vermiculite, $\mathrm{H}$ = hydroxy-interlayered vermiculite(HIV), I = illite, $\mathrm{K}=$ kaolinite. Symbols of +: $<10 \mathrm{~g} \mathrm{~kg}^{-1},++: 10-25 \mathrm{~g} \mathrm{~kg}^{-1},+++: 25-50 \mathrm{~g} \mathrm{~kg}{ }^{-1}$, ++++: $50-75 \mathrm{~g} \mathrm{~kg}^{-1}$. The

semiquantitative mineralogical compositions were estimated by peak areas of XRD to phyllosilicate.

d $\mathrm{G}=$ goethite, $\mathrm{B}=$ birnessite, $\mathrm{L}$ = lithiophorite. 

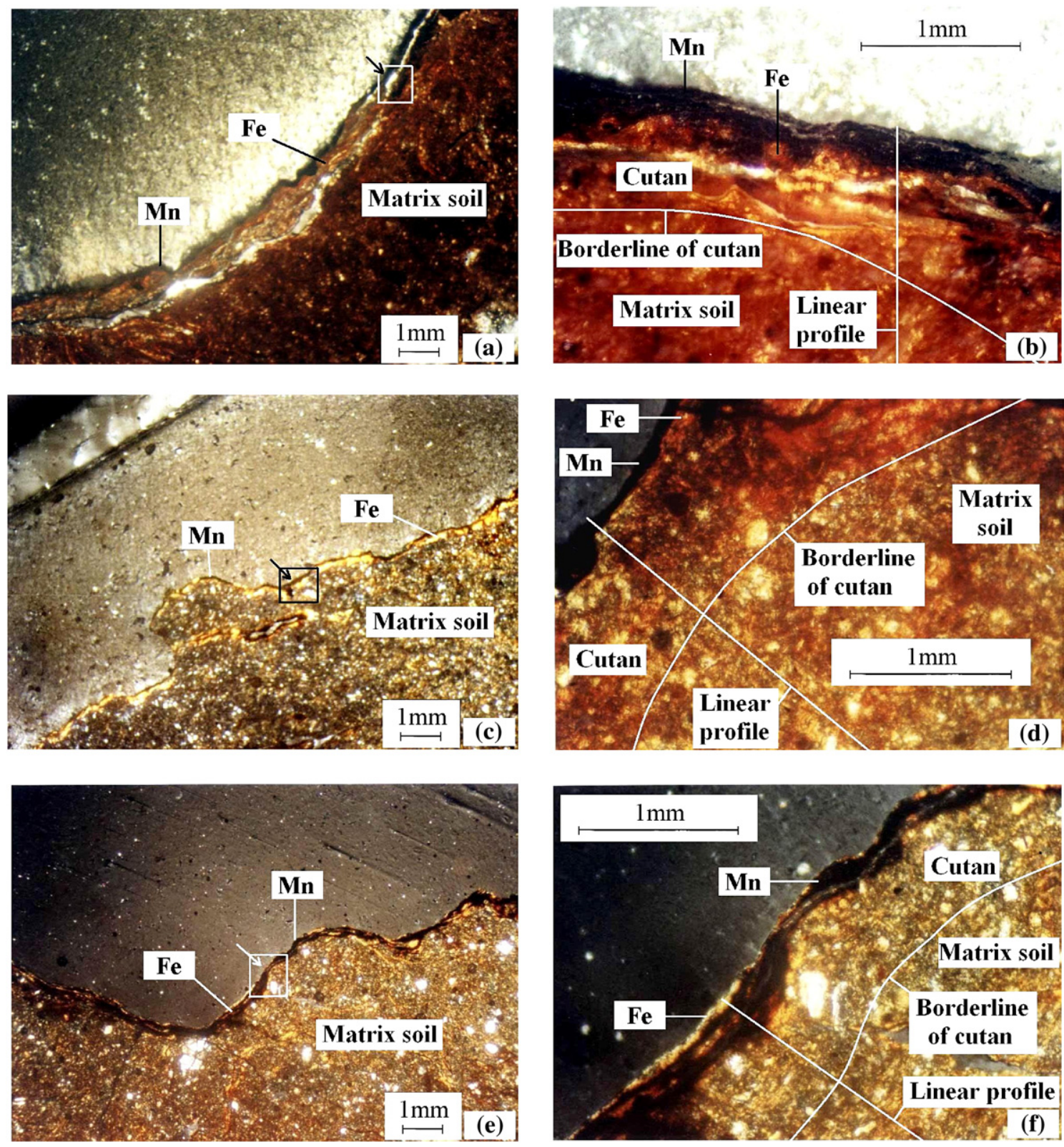

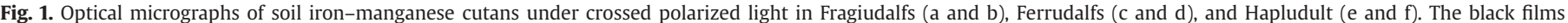

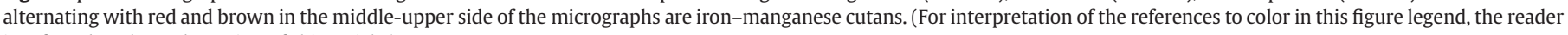
is referred to the web version of this article.)

The deposition of $\mathrm{MnO}_{2}$ was later than that of $\mathrm{Fe}_{2} \mathrm{O}_{3}$, but the deposited layer was thicker (about $0.4 \mathrm{~mm}$ ).

The inner layer of cutans (Fig. 1(c) and (d)) in Ferrudalfs of Wuhan City was mainly composed of thicker reddish-brown $\mathrm{Fe}_{2} \mathrm{O}_{3}$, while the outer layer comprised mainly of dense black $\mathrm{MnO}_{2}$. The transition of the outer layer and the inner layer was clear. Obviously, there was a gradient of red $\mathrm{Fe}_{2} \mathrm{O}_{3}$ deposition between the inner layer and the matrix soil, and $\mathrm{Fe}_{2} \mathrm{O}_{3}$ reduced gradually from the outer to inner layer. These indicated that iron cutan was formed first, followed by manganese cutan in the subsequent formation of cutans, causing $\mathrm{MnO}_{2}$ to cover $\mathrm{Fe}_{2} \mathrm{O}_{3}$. The layer of $\mathrm{MnO}_{2}$ (about $0.2 \mathrm{~mm}$ ) on the surface of cutan in Ferrudalfs was thinner than that in Fragiudalfs, but the deposition gradient of $\mathrm{Fe}_{2} \mathrm{O}_{3}$ was more significant than that in Fragiudalfs of Xinyang City.

The cutans in Hapludult of Taoyuan City (Fig. 1(e) and (f)) were black film mixed with reddish-brown substance, and had a clear black and red belt. The superficial coating was reddish-brown $\mathrm{Fe}_{2} \mathrm{O}_{3}$, and the subsurface stratum was black $\mathrm{MnO}_{2}$, then they alternated with the inner layer composed mainly of $\mathrm{Fe}_{2} \mathrm{O}_{3}$. The transition zone between cutan and matrix soil was obvious. Compared with the cutans of Fragiudalfs and Ferrudalfs, the Hapludult cutan showed a remarkable characteristic of black belts alternating with red ones, and the thickness of cutan material was beyond $0.4 \mathrm{~mm}$. This indicated that the deposition of $\mathrm{Fe}_{2} \mathrm{O}_{3}$ was more obvious than that of $\mathrm{MnO}_{2}$ in the forming process of cutans in Hapludult.

The belt structure of cutan in Hapludult was more complicated compared with that of the other cutans. It presented the multilayered cutan of manganese alternating with iron, revealing that the strong reduced situation caused iron and manganese to emigrate from the matrix soils massively, and gathered in the soil cracks or pores. The cutans of Fragiudalfs and Ferrudalfs were compound cutans composed of thick $\mathrm{Fe}_{2} \mathrm{O}_{3}$ and $\mathrm{MnO}_{2}$. The environmental transition in their forming process possibly was less frequent than that in the Hapludult region. The microstructure of cutans demonstrated that the material 
Table 4

The mean values of element contents in the linear profiles of samples tested

\begin{tabular}{|c|c|c|c|c|c|c|c|c|c|c|c|c|c|}
\hline \multirow[t]{2}{*}{ Samples } & \multirow[t]{2}{*}{ Items } & $\mathrm{SiO}_{2}$ & $\mathrm{TiO}_{2}$ & $\mathrm{Al}_{2} \mathrm{O}_{3}$ & $\mathrm{Fe}_{2} \mathrm{O}_{3}$ & $\mathrm{MnO}_{2}$ & $\mathrm{~K}_{2} \mathrm{O}$ & $\mathrm{Na}_{2} \mathrm{O}$ & $\mathrm{CaO}$ & $\mathrm{MgO}$ & Total & \multirow[t]{2}{*}{$\mathrm{Mn} / \mathrm{Fe}^{\mathrm{a}}$} & \multirow[t]{2}{*}{$\mathrm{Si} / \mathrm{Al}^{\mathrm{b}}$} \\
\hline & & wt.\% & & & & & & & & & & & \\
\hline \multirow[t]{2}{*}{ Cutan of FRA $\left(n^{\mathrm{c}}=16\right)$} & Mean & 45.60 & 1.02 & 21.08 & 9.79 & 7.27 & 2.91 & 0.17 & 1.32 & 1.97 & 91.14 & 0.71 & 17.37 \\
\hline & C.V. ${ }^{\mathrm{d}}$ & 16.43 & 186.16 & 16.23 & 22.67 & 100.24 & 63.32 & 137.63 & 33.69 & 69.25 & 2.41 & 99.46 & 29.89 \\
\hline \multirow[t]{2}{*}{ Matrix of FRA $(n=10)$} & Mean & 49.16 & 0.46 & 24.16 & 8.71 & 0.10 & 2.84 & 0.09 & 0.75 & 1.99 & 88.26 & 0.01 & 16.12 \\
\hline & C.V. & 6.70 & 52.33 & 12.84 & 26.87 & 89.08 & 48.12 & 83.92 & 57.29 & 32.49 & 3.32 & 100.92 & 18.35 \\
\hline \multirow[t]{2}{*}{ Cutan of FER $(n=12)$} & Mean & 37.64 & 0.55 & 20.84 & 12.14 & 11.64 & 2.47 & 0.05 & 0.75 & 1.05 & 87.13 & 0.85 & 14.58 \\
\hline & C.V. & 20.15 & 45.51 & 19.80 & 21.00 & 91.86 & 31.30 & 128.02 & 27.06 & 23.00 & 6.23 & 88.24 & 33.42 \\
\hline \multirow[t]{2}{*}{ Matrix of FER $(n=8)$} & Mean & 48.07 & 0.63 & 27.35 & 9.78 & 0.14 & 2.07 & 0.14 & 0.52 & 1.10 & 89.81 & 0.01 & 13.86 \\
\hline & C.V. & 8.19 & 28.34 & 9.48 & 11.44 & 39.12 & 22.15 & 21.14 & 27.63 & 17.85 & 0.74 & 34.46 & 19.82 \\
\hline \multirow[t]{2}{*}{ Cutan of HAP $(n=11)$} & Mean & 36.61 & 0.88 & 24.08 & 13.99 & 10.04 & 2.91 & 0.16 & 0.64 & 1.00 & 90.31 & 0.60 & 11.88 \\
\hline & C.V. & 27.63 & 71.52 & 15.28 & 25.94 & 97.36 & 27.61 & 65.37 & 68.49 & 22.79 & 1.17 & 92.48 & 29.68 \\
\hline \multirow[t]{2}{*}{ Matrix of HAP $(n=7)$} & Mean & 46.45 & 0.50 & 27.78 & 11.08 & 0.01 & 1.94 & 0.09 & 0.29 & 1.02 & 89.15 & 0.00 & 13.28 \\
\hline & C.V. & 8.89 & 17.44 & 12.82 & 18.34 & 223.61 & 47.04 & 64.01 & 68.79 & 25.17 & 1.94 & 223.61 & 22.07 \\
\hline
\end{tabular}

a $\mathrm{Mn} / \mathrm{Fe}$ molar ratio.

b $\mathrm{Si} / \mathrm{Al}$ molar ratio.

c $n=$ the number of EDS single point analysis.

d C.V. (coefficient of variation) $=$ standard deviation $/$ mean value $\times 100$.

deposition in cutans transformed mainly from $\mathrm{MnO}_{2}$ to $\mathrm{Fe}_{2} \mathrm{O}_{3}$ gradually from Fragiudalfs, Ferrudalfs to Hapludult.

\subsection{Element contents in linear profiles of iron-manganese cutans}

Table 4 shows soil linear profiles analyzed by EDS. The percentages of $\mathrm{TiO}_{2}, \mathrm{~K}_{2} \mathrm{O}, \mathrm{Na}_{2} \mathrm{O}$ and $\mathrm{CaO}$ of sampling spots in the iron-manganese cutans were generally higher than those in the matrix soils. The $\mathrm{SiO}_{2}$ and $\mathrm{Al}_{2} \mathrm{O}_{3}$ contents in the cutans were all lower than those in the matrix soils. However, the $\mathrm{Si} / \mathrm{Al}$ molar ratios in cutans were quite close to those in the matrix soils. This was similar to that of aluminosilicate coatings and groundmass in Guadeloupe Andisol (Jongmans et al., 1994) and that of wall-shaped bridge and coatings in a hard sandyloam soil from semiarid Northern Cameroon (Lamotte et al., 1997). The $\mathrm{Fe}_{2} \mathrm{O}_{3}$ and $\mathrm{MnO}_{2}$ contents in cutan were all higher than those in the matrix soils. In particular, the contents of $\mathrm{MnO}_{2}$ in the cutans were 73, 83 and 1004 times greater than those in the matrix soils, respectively. The change in $\mathrm{Mn} / \mathrm{Fe}$ molar ratio reflected the separation and accumulation of iron and manganese along with the change in soil environmental conditions. The Mn/Fe molar ratios of cutans in three soils all were bigger than those in matrix soils. This indicated that manganese, compared with iron, was easier to accumulate in the cutans in the transition from matrix soils to cutans.

The variation coefficients of major elements in cutans were greater than those in the matrix soils. The variation coefficient of $\mathrm{MnO}_{2}$ in cutans of three soils were was $1.13,2.35$ and 0.44 times greater than those in the matrix soils, but the variation coefficient of $\mathrm{Fe}_{2} \mathrm{O}_{3}$ in cutans were was $0.84,1.84$ and 1.41 times greater than that in the matrix soils, respectively.

In addition, even in the spot-position of cutans where the contents of iron and manganese were very high (about 40\%), the contents of silicon and aluminum still accounted for a great proportion. This was similar to the element composition in dark reddish void coatings that were dominated by $\mathrm{Si}, \mathrm{Al}$ and $\mathrm{Fe}$ in Lower Cretaceous Paleosols in Canada (McCarthy et al., 1999). The most possible migration form of iron and manganese was the colloidal phases (Dixon and Skinner, 1992). Iron and manganese in tested soils were oxidized to deposit on the soil surface, cracks and channels, and they were often accompanied with migration and deposition of layered aluminosilicate clays, as reported by Lamotte et al. (1997).

\subsection{Distribution curves of parts of elements in iron-manganese cutan profile}

The changes of elements with linear microprofiles in the cutans and the matrix soils from the outer to inner layers can be examined by EDS analysis.
Fig. 2(a) shows in Fragiudalfs that the thickness of cutan was within $1 \mathrm{~mm}$, as suggested by Sullivan and Koppi (1991) on composite coatings in desert loam soil. The change range of $\mathrm{CaO}$ was higher than that of $\mathrm{Fe}_{2} \mathrm{O}_{3}$, but the change range of $\mathrm{MnO}_{2}$ content was greater than those of $\mathrm{Fe}_{2} \mathrm{O}_{3}$ and $\mathrm{CaO}$. The content of $\mathrm{SiO}_{2}$ increased gradually from outside to inside. Extending from cutans to the interior of matrix soils, $\mathrm{MnO}_{2}$ trended to reduce gradually, and its content in the matrix approached to zero, the content of $\mathrm{Fe}_{2} \mathrm{O}_{3}$ and $\mathrm{CaO}$ reduced gradually, but $\mathrm{SiO}_{2}$ increased slightly. In the outer layer of cutan (about $0-0.4 \mathrm{~mm}$ ), the average $\mathrm{MnO}_{2}$ content was about $20 \%$, but $\mathrm{Fe}_{2} \mathrm{O}_{3}$ was less than $10 \%$ and $\mathrm{CaO}$ approached $2 \%$. Thus, this region was manganese-rich. In the middle layer of cutan (i.e., about $0.4-0.7 \mathrm{~mm}$ ), the $\mathrm{MnO}_{2}$ content decreased slightly and the $\mathrm{Fe}_{2} \mathrm{O}_{3}$ content increased gradually, $\mathrm{CaO}$ reduced to approximately $1.2 \%$, so this was an iron-manganese-rich region. In the interior of cutan (about 0.7-1.0 mm), the $\mathrm{MnO}_{2}$ content was extremely low, but $\mathrm{Fe}_{2} \mathrm{O}_{3}$ content rose, while $\mathrm{CaO}$ decreased slightly, so this was an iron-rich region. In the $1 \mathrm{~mm}$ thick cutan from outside to inside, the Mn/Fe molar ratio (Fig. 2(b)) presented three obvious peaks.

The thickness of cutan was within $1 \mathrm{~mm}$ in Ferrudalfs (Fig. 2(c)). From the outside to inside of cutans, in a region of $0-0.2 \mathrm{~mm}$, the content of $\mathrm{MnO}_{2}$ (i.e., about $20 \%$ in average) was two times higher than that of $\mathrm{Fe}_{2} \mathrm{O}_{3}$ (about $10 \%$ in average), while the content of $\mathrm{CaO}$ was approximately $1.3 \%$. This was manganese-rich region. In the $0.2-$ $0.5 \mathrm{~mm}$ region, the $\mathrm{MnO}_{2}$ content reduced slightly and was close to $\mathrm{Fe}_{2} \mathrm{O}_{3}$, while $\mathrm{CaO}$ reduced to approximately $0.7 \%$. This was an ironmanganese-rich region. In the $0.5-0.9 \mathrm{~mm}$ region, the content of $\mathrm{MnO}_{2}$ reduced rapidly, and the change of $\mathrm{Fe}_{2} \mathrm{O}_{3}$ was not significant. The content of $\mathrm{CaO}$ reduced to approximately $0.5 \%$, so this was an ironrich region. In the iron-manganese-rich region, the content of $\mathrm{Fe}_{2} \mathrm{O}_{3}$ was higher than that in Fragiudalfs, and the difference of content between $\mathrm{Fe}_{2} \mathrm{O}_{3}$ and $\mathrm{MnO}_{2}$ was smaller than that in Fragiudalfs. The $\mathrm{Mn} /$ Fe molar ratio (Fig. 2(d)) had two obvious peaks in cutan, but it approached zero in the matrix soils.

The changes of elements with linear microprofiles in cutan of Hapludult (Fig. 2(e)) were different from other two kinds of soils. In the outer layer of the cutan (approximately 0-0.4 mm), the content of $\mathrm{MnO}_{2}$ was close to that of Ferrudalfs. The distribution curve of $\mathrm{Fe}_{2} \mathrm{O}_{3}$ was close to that of $\mathrm{MnO}_{2}$, indicated that this was an ironmanganese-rich region. In the inner layer of cutan (approximately 0.4-1.0 mm), the $\mathrm{MnO}_{2}$ content reduced obviously and approached zero. The change of $\mathrm{Fe}_{2} \mathrm{O}_{3}$ content was not obvious. it was an ironrich region. This demonstrated that no manganese-rich region existed in the cutan of Hapludult. In the iron-manganese-rich region of cutan, from outside to inside fluctuation of $\mathrm{CaO}$ content decreased gradually. In the iron-rich region, the $\mathrm{CaO}$ content (approximately $0.5 \%$ ) was lower than the former two kinds of soils. In the matrix 

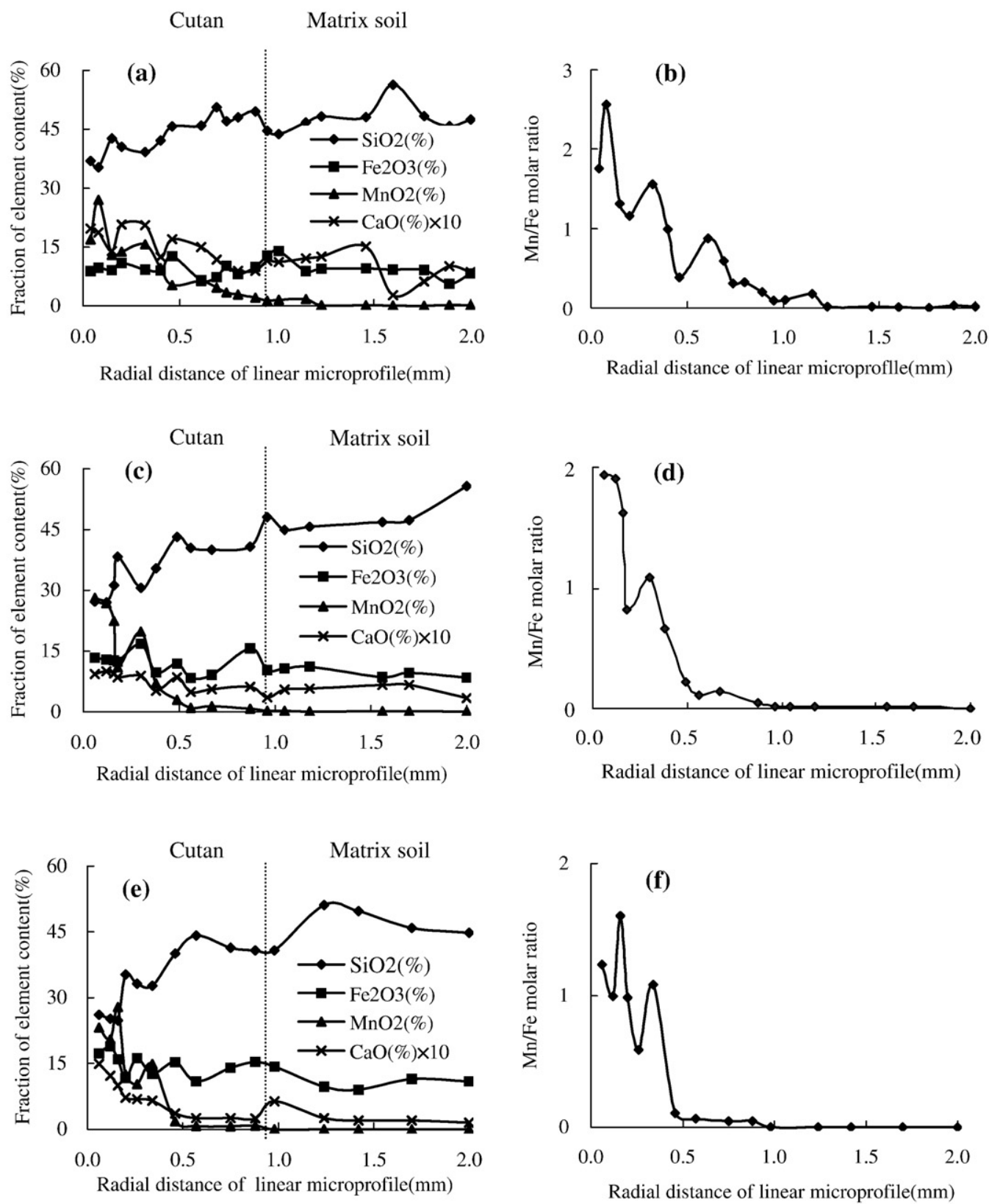

Fig. 2. Distributions of certain elements and Mn/Fe molar ratio in iron-manganese cutan linear profile in Fragiudalfs (a and b), Ferrudalfs (c and d) and Hapludult (e and f).

region, the content of $\mathrm{MnO}_{2}$ approached zero, while the content of $\mathrm{CaO}$ was approximately $0.3 \%$ (lower than Fragiudalfs and Ferrudalfs), and $\mathrm{Fe}_{2} \mathrm{O}_{3}$ was approximately $11 \%$ (higher than Fragiudalfs and Ferrudalfs). The content of $\mathrm{SiO}_{2}$ in Hapludult was higher than other elements, and was close to that in Fragiudalfs and Ferrudalfs. The change range of Mn/Fe molar ratio (Fig. 2(f)) in cutan had two peaks.

\section{Discussion}

The formation of belt structures in iron-manganese cutans was correlated with soil moisture, redox condition, $\mathrm{pH}$, material source, landscape, etc. The standard redox potential $\left(\mathrm{Eh}^{\circ}\right)$ of manganese system is generally higher than that of the iron system (Lindsay, 1979), such as $\mathrm{Eh}^{\circ}$ is $1.23 \mathrm{~V}$ for $\mathrm{MnO}_{2}-\mathrm{Mn}$ (II) system and $0.77 \mathrm{~V}$ for $\mathrm{Fe}$ (III)-Fe (II) system. Therefore, manganese is generally more easily reduced but more difficult to be oxidized than iron (McKenzie, 1989; Huang, 1991). The range of $\mathrm{pH}$ and Eh for Mn (II) to exist in soil is greater than that of Fe (II). Mn (II) would migrate from the matrix soil, which was far away from the microzone of cutan, but the migration distance of Fe (II) was much smaller (Lindsay, 1979; Tan et al., 2005). During iron-manganese cutan forming process, the spatial variation of manganese was higher than that of iron. The contents of $\mathrm{MnO}_{2}, \mathrm{Fe}_{2} \mathrm{O}_{3}$ and $\mathrm{CaO}$ and $\mathrm{Mn} / \mathrm{Fe}$ molar ratios fluctuated 
from the interior to the outside of the cutan profile, all indicating that the soil was under relatively arid or moist environment in different cycle. If the change of wetting and drying is strong, it was advantageous for the separation of manganese and iron oxide, formed the manganese-rich or iron-rich belt structure. If the intensity of soil moisture and aridity was weak and the alternation speed was fast, iron and manganese were not easily separated, thus forming the iron-manganese symbiotic belt structure. Padmanabhan and Mermut (1996) described a similar migration process within the Fe-oxide coatings developed on quartz grains. These belt structures were similar to the layers of Fe- and Mn-rich material observed in many manganese-iron nodules (White and Dixon, 1996; Liu et al., 2002a).

There were iron-manganese-rich and iron-rich regions in cutans of Hapludult, but no manganese-rich region. Compared with Fragiudalfs and Ferrudalfs, Hapludult was in the typical subtropical climate zone of high temperature and rainfall. Here, the soil underwent intensive desilicification and allitization, its $\mathrm{pH}$ was lower than that in Fragiudalfs and Ferrudalfs, and the clay and kaolinite contents increased. So, there was a significant amount of transportable Fe (II) and Mn (II) under the moist and low pH condition in Hapludult, and the migration intensity of iron and manganese increased. It was thus easier to form iron-manganese-rich deposits in cutans of Hapludult than the other soils. From Hapludult, Ferrudalfs to Fragiudalfs, the climate became dry, the acidic leaching function weakened, and the base content and $\mathrm{pH}$ value increased. Compared with $\mathrm{Fe}_{2} \mathrm{O}_{3}$, the content of $\mathrm{MnO}_{2}$ obviously increased, and its function emerged gradually in the cutan forming process.

In summary, soil weathering destroyed phyllosilicate and released massive Fe (II) and Mn (II). The migration of water caused them to emigrate out of the soil interior to reach the surface of the soil body or moved from the surface layer to the alluvial horizon. Then soil environment became dry, which caused the dissolved Fe (II) and Mn (II) to be oxidized and deposited on cracks or surfaces of soil structure bodies. The emigration of base ions also caused pHs in three matrix soils all were lower than those in three cutans, and the results led iron and manganese more easy to dissolve and emigrate from matrix soil to deposit on cutans in the cutan forming processes. The formation of iron-manganese cutan depended much on landscape setting which directly influenced the soil moisture and wet and dry cycles. The tested three soils all located on hills which had good drainage condition, it made the layers of iron and manganese deposition in cutans limited because of the long length of alternation cycle. Further more, the subtropical area had a unique climate that formed an environment of wetting and drying cycles in the soils. The soil properties had the obvious characteristic of transition from north to south in this area in China. Although the base ions were leached out massively, the iron-manganese oxides were still in the stage of frequent migration and deposition, this was also the main reason why the iron-manganese cutans were widely distributed in the subtropical soils. The belt structure character and the distribution of iron-manganese cutans had further instructed the pedogenic process and climatic conditions in the different soils. Therefore, it may be reasonable and significant to regard the material composition and belt characteristic of iron-manganese cutan as the result of soil forming over the long-term evolution. Further research on the formation of soil cutans could gain information of certain historical environmental transformations.

\section{Acknowledgements}

We thank Dr. Huifang Liu, Associate Professor of State Key Laboratory of Geological Processes and Mineral Resources in China, University of Geosciences, for his assistance with the sample analysis. We appreciate Miss Xianping Luo for doing some research work on this project. This research was supported by the National Natural
Science Foundation of People's Republic of China (Grant No. 40071048) and the Foundation for the Author of National Excellent Doctoral Dissertation of China (Grant No. 200767).

\section{References}

Boulet, R., Fritsch, E., Filizola, H.F., de Araujo Filho, J.C., Leprun, J.C., Barretto, F., Balan, E., Tessier, D., 1998. Iron bands, fragipans and duripans in the northeastern plateaus of Brazil-properties and genesis. Can. J. Soil Sci. 78, 519-530.

Brewer, R., 1976. Fabric and Mineral Analysis of Soils. Robert E. Krieger Publishing Huntington, NY, pp. 205-233.

Buol, S.W., Hole, F.D., 1959. Some characteristics of clay skins on peds in the B Horizon of a gray-brown podzolic soils. Soil Sci. Soc. Amer. Proc. 23, 239-241.

Chartres, C.J., 1987. The composition and formation of grainy void cutans in some soils with textural contrast in Southeastern Australia. Geoderma 39, 209-233.

Dixon, J.B., Skinner, H.C.W., 1992. Manganese minerals in surface environments. In: Skinner, H.C.W., Itzpatrick, R.W. (Eds.), Biomineralization Processes of Iron and Manganese-Modern and Ancient Environments. Catena Verlag, Cremlingen, pp. 31-50.

Feijtel, T.C., Jongmans, A.G., van Doesburg, J.D.J., 1989. Identification of clay coatings in older quaternary terrace of the Allier, Limagne, France. Soil Sci. Soc. Am. J. 53, 876-882.

FitzPatrick, E.A., 1984. Micromorphology of Soils. Chapman and Hall, London.

Gee, G.W., Bauder, J.W., 1986. Particle-size analysis. In: Klute, K. (Ed.), Methods of Soil Analysis. Part I. Agronomy Monograph, vol. 9. American Society of Agronomy, Madison, WI, USA, pp. 383-411.

Harris, W.G., Carlisle, V.W., Van Rees, K.C.J., 1987. Pedon zonation of hydroxyinterlayered minerals in Ultic Haplaquods. Soil Sci. Soc. Am. J. 51, 1367-1372.

Hartres, C.J., 1987. The composition and formation of grainy void cutans in some soils with textural contrast in southeastern Australia. Geoderma 39, 209-233.

Hopkins, D.G., Franzen, D.W., 2003. Argillic horizons in stratified drift luverne end moraine, Eastern North Dakota. Soil Sci. Soc. Am. J. 67, 1790-1796.

Huang, P.M., 1991. Kinetics of redox reactions on manganese oxides and its impact on environmental quality. In: Sparks, D.L., Suarez, D.L. (Eds.), Rate of Soil Chemica Processes. Publ. 27. Soil Science Society of America, Madison, WI, USA, pp. 191-230.

Huang, L., Tan, W.F., Liu, F., Hu, H.Q., Huang, Q.Y., 2007. Composition and transformation of $1.4 \mathrm{~nm}$ minerals in cutan and matrix of Alfisols in central China. J. Soils Sedim. 7 240-246.

Jackson, M.L., 1979. Soil Chemical Analysis. Advanced Course, 2nd edn. University of Wisconsin, Madison, WI, U.S.A.

Jongmans, A.G., Veldkamp, E., van Breemen, N., Staritsky, I., 1993. Micromorphological characterization and microchemical quantification of weathering in an alkali basalt pebble. Soil Sci. Soc. Am. J. 57, 128-134

Jongmans, A.G., van Oort, F., Buurman, P., Jaunet, A.M., van Doesburg, J.D.J., 1994. Morphology, chemistry, and mineralogy of isotropic aluminosilicate coatings in a Guadeloupe Andisol. Soil Sci. Soc. Am. J. 58, 501-507.

Jongmans, A.G., Mulder, J., Groenesteijn, K., Buurman, P., 1996. Soil surface coatings at costa Rican recently active volcanoes. Soil Sci. Soc. Am. J. 60, 1871-1880.

Khormali, F., Abtahi, A., Stoops, G., 2006. Micromorphology of calcitic features in highly calcareous soils of Fars Province, Iran. Geoderma 132, 31-46.

Lamotte, M., Bruand, A., Ohnenstetter, D., Ildefonse, P., Pédro, G., 1997. A hard sandyloam soil from semi-arid northern Cameroon: II. Geochemistry and mineralogy of the bonding agent. Eur. J. Soil Sci. 48, 227-237.

Lindsay, W.L., 1979. Chemical Equilibria in Soils. John Wiley and Sons, New York.

Liu, F., Gilkes, R.J., Hart, R.D., Bruand, A., 2002a. Differences in potassium forms between cutans and adjacent soil matrix in a grey clay soil. Geoderma 106, 289-303.

Liu, F., Colombo, C., Adamo, P., He, J.Z., Violante, A., 2002b. Trace elements in manganese-iron nodules from a Chinese Alfisol. Soil Sci. Soc. Am. J. 66, 661-670.

McCarthy, P.J., Martini, I.P., Leckie, D.A., 1999. Pedogenic and diagenetic influences on void coating formation in Lower Cretaceous paleosols of the Mill Creek Formation, southwestern Alberta, Canada. Geoderma 87, 209-237.

McKeague, J.A., Day, J.H., 1966. Dithionite- and oxalate-extractable $\mathrm{Fe}$ and $\mathrm{Al}$ as aids in differentiating various classes of soils. Can. J. Soil Sci. 46, 13-22.

McKenzie, R.M., 1989. Manganese oxides and hydroxides, In: Dixon, J.B., Weed, S.B. (Eds.), Minerals in Soil Environments, 2nd edn. Soil Science Society of America, Madison, WI, USA, pp. 439-465.

Mehra, O.P., Jackson, M.L., 1960. Iron oxide removal from soils and clays by a dithionitecitrate system buffered with sodium bicarbonate. Clays Clay Miner. 7, 317-327.

Padmanabhan, E., Mermut, A.R., 1996. Submicroscopic structure of Fe-coatings on quartz grains in tropical environments. Clays Clay Miner. 44, 801-810.

Payton, R.W., 1993. Fragipan formation in argillic brown earths (Fragiudalfs) of the Milfield Plain, North-east England III. Micromorphological, SEM and EDXRA studies of fragipan degradation and the development of glossic features. Soil Sci. 44, 725-739.

Pustovoytov, K.E., 2002. Pedogenic carbonate cutans on clasts in soils as a record of history of grassland ecosystems. Palaeogeogr. Palaeoclimatol. Palaeoecol. 177, 199-214.

Rebertus, R.A., Buol, S.W., 1985. Intermittency of illuviation in dystrochrepts and hapludults from the piedmont and blue ridge provinces of north Carolina. Geoderma 36, 277-291.

Robinson, G.D., 1993. Major-element chemistry and micromorphology of Mn-oxide coatings on stream alluvium. J. Geochem. Explor. 8, 633-642.

Schulze, D.C., Dixon, J.B., 1979. High gradient magnetic separation of iron oxides and other magnetic minerals from soil clays. Soil Sci. Soc. Am. J. 43, 793-799. 
Soil Survey Staff, 2006. Keys to Soil Taxonomy, 10th ed. United States Department of Agriculture, Washington D.C., USA.

Sullivan, L.A., Koppi, A.J., 1991. Morphology and genesis of silt and clay coatings in the vesicular layer of a desert loam soil. Aust. J. Soil Res. 29, 579-586.

Tan, W., Liu, F., Feng, X., Huang, Q., Li, X., 2005. Adsorption and redox reaction of heavy metals on Fe-Mn nodules from Chinese soils. J. Colloid Interface Sci. 284, 600-605.

Tsatskin, A., Ronen, A., 1999. Micromorphology of a Mousterian paleosol in aeolianites at the site Habonim, Israel. Catena 34, 365-384.

Venugopal, K.R., 1998. Types of cutans in some ferruginous soils of Bangalore plateau and their relation with soil development. J. Indian Soc. Soil Sci. 46, 641-646.
Walkley, A., Black, C.A., 1934. An experimentation of the Detareff method, and a proposed modification of the chromic acid titration method. Soil Sci. 37, 29-39.

White, G.N., Dixon, J.B., 1996. Iron and manganese distribution in nodules from a young Texas Vertisols. Soil Sci. Soc. Am. J. 60, 1254-1262.

Zhang, M., Karathanasis, A.D., 1997. Characterization of iron-manganese concretions in Kentucky Alfisols with perched water tables. Clays Clay Miner. 45, 428-439. 